\title{
Informing with Case Studies: Panel Discussion
}

\author{
T. Grandon Gill \\ University of South Florida, \\ Tampa, FL, USA
}

grandon@usf.edu

\author{
John Ickis \\ INCAE Business School, \\ La Garita, Alajuela, Costa Rica \\ john.ickis@incae.edu
}

\author{
Kevin Johnston \\ University of Cape Town, Cape Town, South Africa
}

kevin.johnston@uct.ac.za

\begin{abstract}
Case writing and case discussions present an interesting informing challenge. While participants often report being informed by both the writing and discussion processes, they similarly find themselves hard-pressed to identify precisely what they learned. This panel will begin with some examples of case studies to facilitate many alternative informing pathways, including 1) student $\rightarrow$ student, 2) instructor $\rightarrow$ student, 3) student $\rightarrow$ instructor, 4) instructor $\rightarrow$ instructor, 5) practice $\rightarrow$ practice, 6) instructor $\rightarrow$ practice, 7) practice $\rightarrow$ instructor, 8) practice $\rightarrow$ student and 9) student $\rightarrow$ practice. We will then discuss some Informing Science initiatives to broaden our understanding of case studies, including the launch of JITE: Discussion Cases and a special issue of Informing Science: The International Journal of an Emerging Transdiscipline on informing with case studies. The panel will then engage the audience in a search for ideas about how we might further encourage faculty and administrative interest in the use of case studies for instruction and research.
\end{abstract}

Keywords: case studies, informing

Material published as part of this publication, either on-line or in print, is copyrighted by the Informing Science Institute. Permission to make digital or paper copy of part or all of these works for personal or classroom use is granted without fee provided that the copies are not made or distributed for profit or commercial advantage AND that copies 1) bear this notice in full and 2) give the full citation on the first page. It is permissible to abstract these works so long as credit is given. To copy in all other cases or to republish or to post on a server or to redistribute to lists requires specific permission and payment of a fee. Contact Publisher@InformingScience.org to request redistribution permission. 


\section{Biographies}

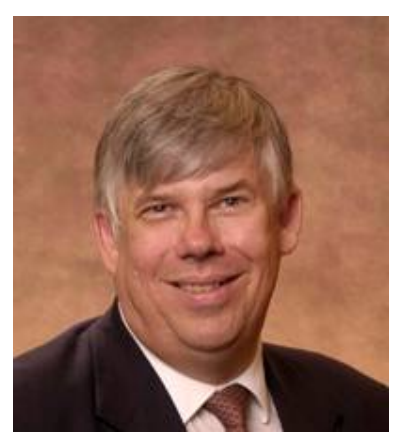

Grandon Gill is a Professor in the Information Systems and Decision Sciences department at the University of South Florida. He holds a doctorate in Management Information Systems from Harvard Business School, where he also received his M.B.A. His principal research areas are the impacts of complexity on decision-making and IS education, and he has published many articles describing how technologies and innovative pedagogies can be combined to increase the effectiveness of teaching across a broad range of IS topics. Currently, he is Editor-inChief of Informing Science: The International Journal of an Emerging Transdiscipline and an Editor of the Journal of Information Technology Education.

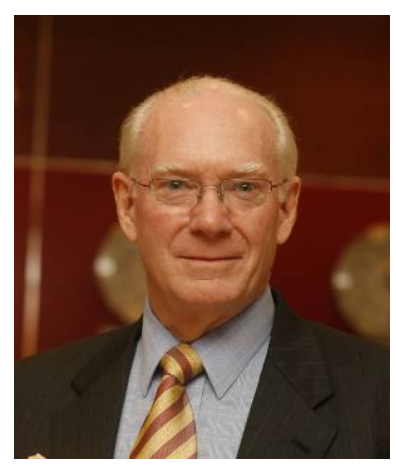

John C. Ickis (M.B.A., D.B.A, Harvard University) is Professor at INCAE (Instituto Centroamericano de Administración de Empresas) Business School, where he teaches in the areas of Strategy and Organization. His area of specialization is in the implementation of change in private, public, and non-profit organizations. He was Visiting International Scholar at the Harvard Business School where he participated in the design of the course, "Managing in Developing Countries" and is co-author of articles on this topic in World Development and The Harvard Business Review. He was selected as case method instructor in Harvard Business School's first Colloquium on Participant-Centered Learning and has conducted case method workshops in a dozen countries of Latin America. As President of the international consulting firm J.E. Austin Associates, he worked with competitiveness programs in Africa and Central Europe, where he led a casewriting initiative in Croatia. As an advisor with the World Bank, he presented alternative models of management education to the Government of the Peoples' Republic of China. He is a member of Who's Who in the World and an honorary citizen of Soweto, South Africa.

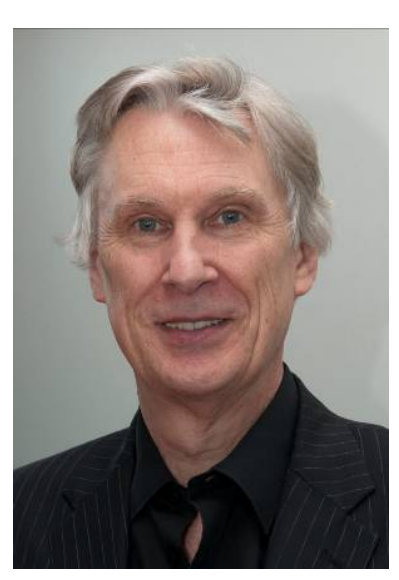

Kevin Johnston is an associate professor in the Department of Information Systems at the University of Cape Town, South Africa. Before becoming an academic, he worked for 24 years in industry. His main areas of research are IS Change, IS Management, and IS education. 